\title{
Glacier and lake variations in the Yamzhog Yumco basin, southern Tibetan Plateau, from 1980 to 2000 using remote-sensing and GIS technologies
}

\author{
Qinghua YE, ${ }^{1,2}$ Liping ZHU, ${ }^{1,3}$ Hongxing ZHENG, ${ }^{3}$ Renji NARUSE, ${ }^{4}$ Xueqin ZHANG, ${ }^{3}$ \\ Shichang KANG ${ }^{1,5}$ \\ ${ }^{1}$ Institute of Tibetan Plateau Research, Chinese Academy of Sciences, Beijing 100085, China \\ E-mail: yeqh@itpcas.ac.cn \\ ${ }^{2}$ State Key Laboratory of Remote Sensing Science, Jointly Sponsored by Institute of Remote Sensing Applications of \\ Chinese Academy of Sciences and Beijing Normal University, Beijing 100101, China \\ ${ }^{3}$ Institute of Geographical Sciences and Natural Resources Research, Chinese Academy of Sciences, Beijing 100101, China \\ ${ }^{4}$ Glacier and Cryospheric Environment Research Laboratory, Higashi-machi 2-339, Tottori 680-0011, Japan \\ ${ }^{5}$ State Key Laboratory of Cryospheric Science, Chinese Academy of Sciences, Lanzhou 730000, China
}

\begin{abstract}
Glacier and lake variations in the Yamzhog Yumco basin in southern Tibet were studied by integrating series of spatial data from topographic maps and Landsat images at three different times: 1980, 1988/90 and 2000. The results indicate that the total glacier area has decreased from $218 \mathrm{~km}^{2}$ in 1980 to $215 \mathrm{~km}^{2}$ in 2000 , a total reduction of $3 \mathrm{~km}^{2}$ (i.e. a $1.5 \%$ decrease). Glacier recession rates were clearly larger in the 1990s than the 1980s due to the warmer climate. The total lake area decreased by about $67 \mathrm{~km}^{2}$ during $1980-90$ and increased by $32 \mathrm{~km}^{2}$ during $1990-2000$. It is suggested that change of lake area in the basin was rapid and most likely caused primarily by the change in precipitation and evaporation in the basin, and secondarily by the increased water supply from melting glaciers.
\end{abstract}

\section{INTRODUCTION}

Extensive studies have been made on alpine glacier variations in high Asia over the last few decades (e.g. Mayewski and Jeschke, 1979; Fujita and others, 2006), and revealed that glacial retreat has occurred widely and asynchronously across the Tibetan Plateau. Under a warmer climate in the future, melting of glaciers will be accelerated in continental regions (Dyurgerov, 2002). As a result, the hydrological systems may be altered significantly; such hydrological events as floods from glacier lakes may cause hazards in mountain regions. Basins located in different regions will experience different impacts of variability in the climate (Chiew and others, 1995). Studying spatial and temporal covariations of glaciers and lakes will help us understand the impact of climate change within a basin in Tibet (Shi and Ren, 1990).

The Yamzhog Yumco ('co' is the Tibetan word for 'lake') is the largest existing inland lake (Liu, 1995) on the northern foot of the Himalaya in southern Tibet (Fig. 1), located in Nagarzê county at more than 4400 ma.s.l. Terraces on the lake shore are well developed, indicating a larger lake area in the past. There are many lakes around the Yamzhog Yumco, constituting a closed drainage basin (hereafter referred to as the Yamzhog basin) with an area of $8840 \mathrm{~km}^{2}$. The average annual precipitation was $373 \mathrm{~mm}$ at Nagarzê station (4432 ma.s.l. in the northwest of Yamzhog basin) during 1961-75 (Guan and others, 1984). This paper presents areal variations of glaciers and lakes in the Yamzhog basin by means of geographical information system (GIS) and remote-sensing (RS) techniques in order to provide some ideas about the impact of climate change on glaciers and lakes in high-altitude basins on the Tibetan Plateau.

\section{METHODOLOGY}

We use four scenes of Landsat images of 137/40 and 138/40 path/row, including Thematic Mapper (TM) on 1 November 1988 and 14 November 1990 (1988/90), i.e. a mosaic image of 2 years to cover the entire basin, and Enhanced TM Plus

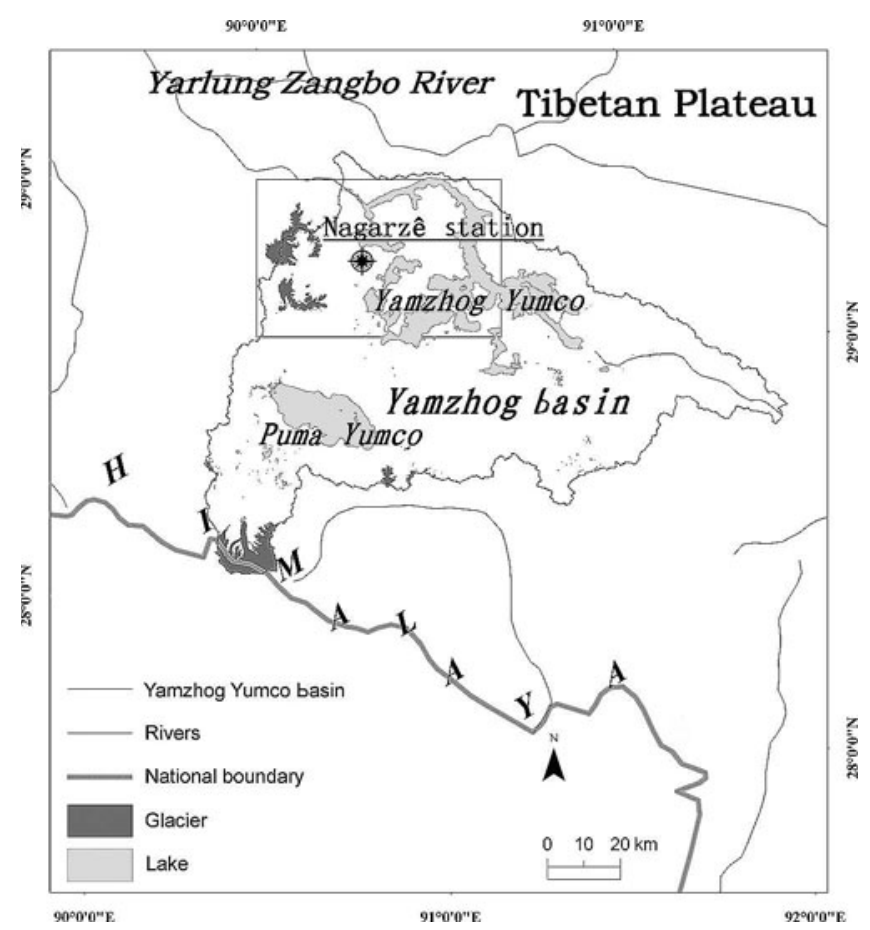

Fig. 1. Map of Yamzhog basin and the surroundings in the Tibetan Plateau. The rectangle indicates the area shown in Figure 2. 


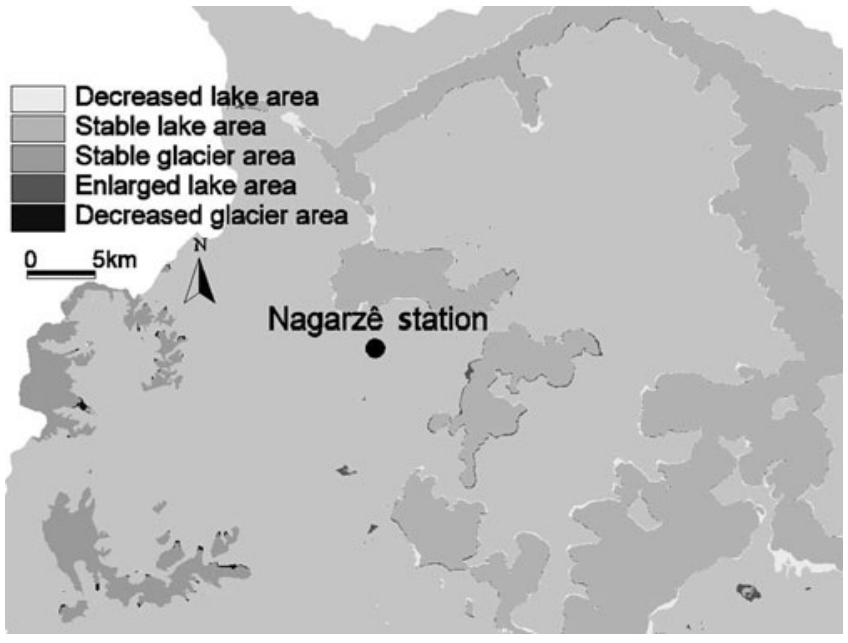

Fig. 2. Variations in areas of glaciers and lakes in Yamzhog basin, 1980-2000.

(ETM+) on 17 November and 28 December 2000. We also use topographic maps at a 1:50000 scale (about $\pm 25 \mathrm{~m}$ accuracy) in 1980 and available digital elevation model (DEM) data (DEM25, cell size: $100 \mathrm{~m}$ ) which come from digitization of the 1:250000 topographic map with contour interval of $100 \mathrm{~m}$ to ortho-rectify all the digital satellite images. The accuracy of ortho-rectification is within one image pixel. The co-registration errors for all ortho-images to the 1:50000 scale topographic maps were within one image pixel, i.e. $25 \mathrm{~m}$. Glaciers and lakes on the 1:50000 scale topographic maps and sequential Landsat images were mapped in the false-color image by on-screen digitizing with manual delineation using Arc/Info software. The accuracy of manual digitization was controlled within one pixel. Changes in the extent of glacier/lakes in the Yamzhog basin were measured with an uncertainty of $\pm 0.015 \mathrm{~km}^{2}$. For detailed methods of analyses and error estimates, refer to Ye and others (2006b).

It should be noted that all images used were taken in winter (November or December). However, because there was very little winter precipitation in the basin (the average winter precipitation was about $5 \mathrm{~mm}$ at Nagarzê station during 1980-2000), there was no substantial seasonal snow cover present to affect the image interpretation.

\section{RESULTS}

Calculating glacier and lake areas from classification of digital images in the Yamzhog basin from 1980 to 2000, we determined that the total glacier and lake areas in 1980 were $218 \mathrm{~km}^{2}$ and $1072 \mathrm{~km}^{2}$, or $2.5 \%$ and $12.1 \%$ of the total basin area, respectively. Changes in area of glaciers and lakes from 1980 to 2000, determined using the hybrid-grid method (Ye and others, 2006b), are summarized in Table 1 and Figure 2. The total glacier recession was about $3 \mathrm{~km}^{2}$ (or $0.15 \mathrm{~km}^{2} \mathrm{a}^{-1}$ on average), and no advancing glaciers were recognized in the basin during this period. Glacier recession accelerated from $0.11 \mathrm{~km}^{2} \mathrm{a}^{-1}$ in the $1980 \mathrm{~s}$ to $0.18 \mathrm{~km}^{2} \mathrm{a}^{-1}$ in the 1990s (Table 1).

Lake variations in the the Yamzhog basin in the last 20 years were more complicated than glacier variations. From the data shown in Table 1, we know that the lake area decreased by $67.39 \mathrm{~km}^{2}$ in total (from 1980 to 1988/90 with lake shrinkage amounting to $76.02 \mathrm{~km}^{2}$ and lake growth to $9.63 \mathrm{~km}^{2}$ ), then it increased by $31.58 \mathrm{~km}^{2}$ in total (from 1988/ 90 to 2000 with lake shrinkage amounting to $11.13 \mathrm{~km}^{2}$ and lake growth to $42.71 \mathrm{~km}^{2}$ ). About $32.58 \mathrm{~km}^{2}$ of lake area (about $3.0 \%$ of the total lake area in the basin) disappeared during 1980-90 but re-emerged during 1990-2000. It seems that reduction in lake area had greatly decreased (from $4.34 \mathrm{~km}^{2} \mathrm{a}^{-1}$ in the $1980 \mathrm{~s}$ to $0.71 \mathrm{~km}^{2} \mathrm{a}^{-1}$ in the $1990 \mathrm{~s}$ ) while enlargement rate increased by a factor of almost two (from $0.51 \mathrm{~km}^{2} \mathrm{a}^{-1}$ in the $1980 \mathrm{~s}$ to $1.01 \mathrm{~km}^{2} \mathrm{a}^{-1}$ in the $1990 \mathrm{~s}$ ). Although lake enlargement in the 1990s did not compensate for the lake reduction in the 1980s, the enlargement trend seems to be in accordance with continuously accelerating glacier recessions in the basin.

\section{DISCUSSION AND CONCLUSIONS}

We now examine glacier and lake variations in the context of meteorological data from Nagarzê station during 19802000. Figure $3 \mathrm{a}$ and $\mathrm{b}$ show time series of average summer air temperature (for April through October where monthly mean temperature is above $0^{\circ} \mathrm{C}$ ) and the annual precipitation in the basin $\left(P_{\mathrm{a}}\right)$. It is noted that the temperature shows

Table 1. Changes in glacier area and lake area in Yamzhog basin, 1980-2000

\begin{tabular}{|c|c|c|c|c|}
\hline Category of variation & $\begin{array}{l}\text { Area } \\
\mathrm{km}^{2}\end{array}$ & $\begin{array}{c}\text { Percentage change } \\
\%\end{array}$ & $\begin{array}{l}\text { Change rate } \\
\qquad \mathrm{km}^{2} \mathrm{a}^{-1}\end{array}$ & $\begin{array}{c}\text { Percentage change rate } \\
\qquad \% \mathrm{a}^{-1}\end{array}$ \\
\hline Quasi-stable lake area & 988.85 & 7.76 & 4.16 & 0.39 \\
\hline Lake that decreased in 1980s but re-emerged in 1990s & 32.58 & 3.04 & 3.26 & 0.30 \\
\hline Lake that enlarged in 1980 s but decreased in 1990s & 4.00 & 0.37 & 0.40 & 0.04 \\
\hline Decreased lake area in 1980 s & 43.44 & 4.05 & 4.34 & 0.41 \\
\hline Decreased lake area in 1990s & 7.13 & 0.71 & 0.71 & 0.07 \\
\hline Enlarged lake area in 1980s & 5.63 & 0.52 & 0.56 & 0.05 \\
\hline Enlarged lake area in 1990s & 10.13 & 1.01 & 1.01 & 0.10 \\
\hline Decreased glacier area in 1980 s & 1.14 & 0.52 & 0.11 & 0.05 \\
\hline Decreased glacier area in 1990 s & 1.84 & 0.85 & 0.18 & 0.08 \\
\hline Quasi-stable glacier area & 214.96 & 1.60 & 0.18 & 0.08 \\
\hline No change background & 7525.51 & & & \\
\hline
\end{tabular}




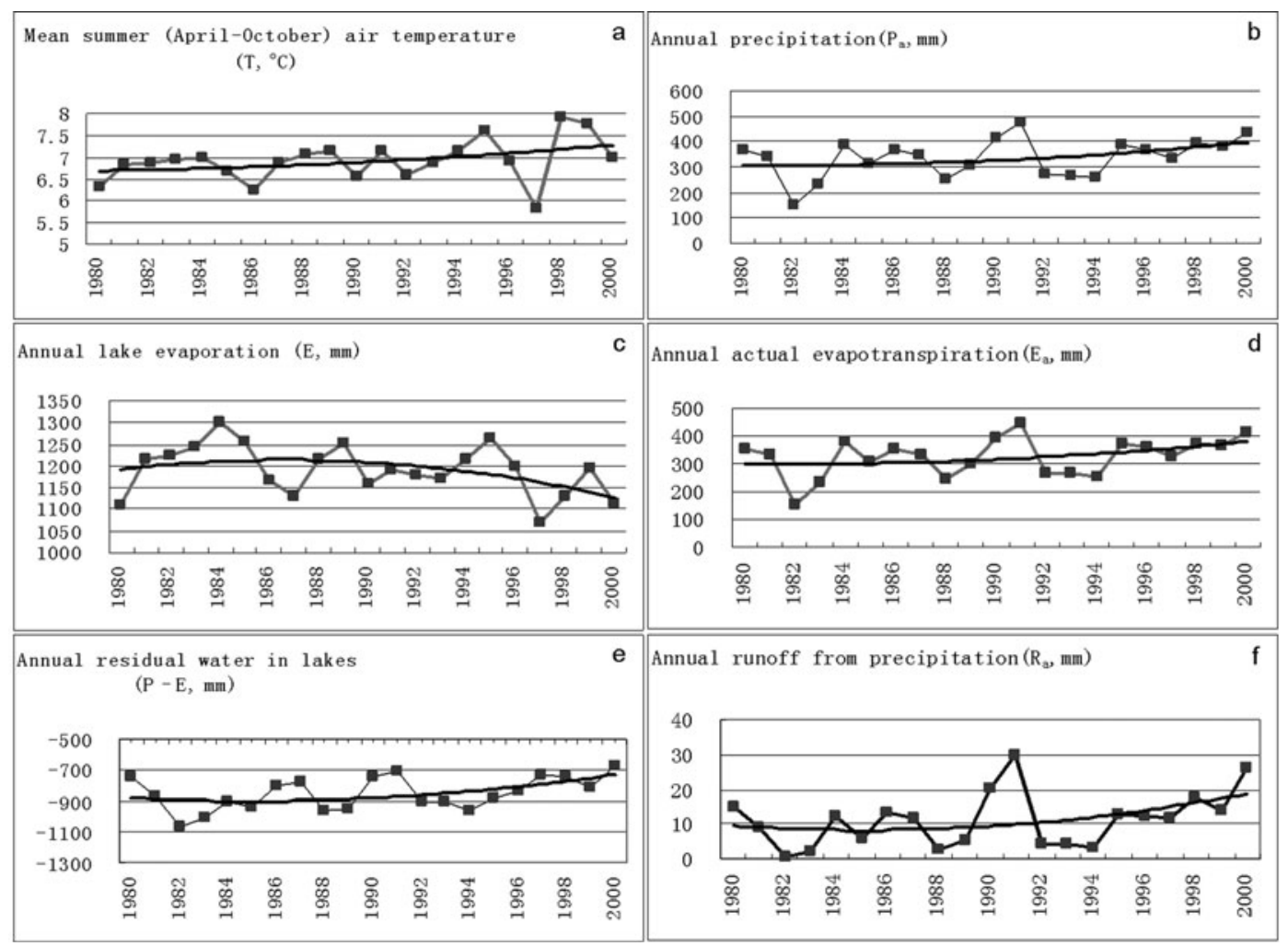

Fig. 3. (a) Mean summer (April-October) air temperature $\left(T,{ }^{\circ} \mathrm{C}\right)$; (b) annual precipitation $\left(P_{\mathrm{a}}, \mathrm{mm}\right)$; (c) annual lake evaporation $(E$, mm); (d) annual actual evapotranspiration in the basin $\left(E_{\mathrm{a}}, \mathrm{mm}\right)$; (e) annual residual water in lakes $(P-E, \mathrm{~mm})$; and (f) annual runoff from precipitation $\left(R_{\mathrm{a}}, \mathrm{mm}\right)$. Data were obtained at Nagarzê station on the Tibetan Plateau. Solid curves indicate trends fitted by polynomial during the period.

a slight increasing trend and the precipitation a clear increasing trend since 1980.

The hydrological factors involved in lake changes are potentially quite complicated. The water balance of the lake can be described as

$$
\begin{aligned}
\Delta W & =P+R-E+\delta \\
R & =R_{\mathrm{a}}+R_{\mathrm{g}},
\end{aligned}
$$

where $\Delta W$ is the change of water stored in the lake, $P$ is annual lake precipitation, $E$ is annual lake evaporation (Fig. 3c), which was obtained by multiplying annual evaporation rate measured daily with a $20 \mathrm{~cm}$ evaporation pan, by a factor of $0.6, R$ is the runoff entering the lake consisting of $R_{\mathrm{g}}$ (i.e. runoff from glacier melting) and $R_{\mathrm{a}}$ (i.e. runoff from precipitation, roughly estimated by $R_{\mathrm{a}}=P_{\mathrm{a}}-E_{\mathrm{a}}$ ) and $\delta$ is a factor due to the other effects (e.g. melting water from frozen grounds, human activities, etc.). Actual terrestrial evapotranspiration of the basin ( $E_{\mathrm{a}}$, Fig. $3 \mathrm{~d}$ ) is calculated using $P_{\mathrm{a}}$ and potential evapotranspiration in the basin (ET) by the Bagrov model (Bagrov, 1953). Owing to the data availability in the study area, we assume $P_{\mathrm{a}}=P$ and $\mathrm{ET}=E$. Units of all parameters in Equations (1) and (2) are mm.

Figure $3 \mathrm{e}$ indicates that, during the past two decades, $P-E$ (i.e. vertical water flux) for all lakes tended to increase from about $-905 \mathrm{~mm}$ in the $1980 \mathrm{~s}$ to $-815 \mathrm{~mm}$ in the $1990 \mathrm{~s}$ as a result of an increase in precipitation (Fig. 3b) and a slight decrease in lake evaporation (Fig. 3C). As shown in Figure $3 \mathrm{f}$, the annual runoff from precipitation $\left(R_{\mathrm{a}}\right)$ increased from an average of about $8 \mathrm{~mm}$ in the $1980 \mathrm{~s}$ to $14 \mathrm{~mm}$ in the 1990s, and it reached $26 \mathrm{~mm}$ in 2000 .
According to Equation (2), the melting of glaciers may also contribute to changes in the lakes because of increasing runoff from glaciers $\left(R_{\mathrm{g}}\right)$. In the Yamzhog basin, the glacier area occupies less than $2.5 \%$ and did not change much from 1980 to 2000 (Table 1), so it seems unlikely to have been the primary reason for such a great change in the lake area in the basin (the lake occupies 12\% area in the basin). However, it should be noted that the effects of glacier recession on lake changes may manifest differently because of the different lake locations and sizes. For smaller lakes near to the glaciers, glacier recessions may result in more obvious changes in lake area than they do for larger lakes far from the glaciers. This contention was supported by our results shown in Figure 2, where some western smaller lakes tended to enlarge corresponding to more remarkable glacier recessions at the terminus in the western part of the Yamzhog basin. The lake area decreased in the east of the basin, where some smaller lakes have totally disappeared.

Therefore, the lake decrease in the Yamzhog basin in the 1980s was most likely due to the larger negative value of $P-E$ and the decreased value of $R_{\mathrm{a}}$, whereas the enlargements of lakes in the 1990s may have resulted from the less negative $P-E$ and increased $R_{\mathrm{a}}$ along with the effect of water from enhanced melting of glaciers $\left(R_{\mathrm{g}}\right)$. Despite the observations above, the precise reasons for lake shrinkage in the Yamzhog basin have not yet been identified quantitatively because of the shortage of regional in situ hydrological data for the study of water balance in the basin (e.g. runoff from melting glaciers, water-level variations of lakes, etc.). Our work has focused on variations in area of glaciers and 
lakes, and (owing to lack of bathymetric data) did not include variations in either lake level or glacier-surface elevation, which would be necessary to extract the information on ice volume and water mass variations.

Our results show that both glacier and lake areas in the Yamzhog basin decreased from 1980 to 2000. Decreases in glacier area during the two decades were not significant; lake areas shrank by $67 \mathrm{~km}^{2}$ in the 1980s, while almost half of that $\left(33 \mathrm{~km}^{2}\right.$, about $3 \%$ of the total lake area in the basin) reemerged in the 1990s. This finding indicates that the lake changes occur over a wider range and more rapidly than the glacier changes. The $1.36 \%$ (or $0.07 \% \mathrm{a}^{-1}$ ) decrease in glacier area in this basin was not dramatic compared with the $0.18 \% \mathrm{a}^{-1}$ mean glacier recession across China since the 1960s (Yao and others, 2004) and the $0.31 \% \mathrm{a}^{-1}$ mean glacier recession in the Naimona'nyi region of the western Himalaya during 1976-2003 (Ye and others, 2006a).

\section{ACKNOWLEDGEMENTS}

This work was jointly supported by Chinese National Basic Research Program (grant No. 2005CB422002), the National Natural Sciences Foundation of China (grant No. 40331006, 40571172, 40601056), Knowledge Innovation Project of Chinese Academy of Sciences (CAS; KZCX3-SW-339), the innovative project of the Institute of Geographical Sciences and Natural Resources Research, CAS (CXIOG-A04-03), Opening Fund projects of State Key Laboratory of Remote Sensing Science in the Institute of Remote Sensing Applications and the 'Talent Project' of CAS. We thank Jinghua Wang and Qinglong You for data digitizing and collections, M. Dyurgerov, an anonymous reviewer and the Scientific Editor J. Walder for helpful comments on the manuscript.

\section{REFERENCES}

Bagrov, N.A. 1953. O srednem mnogoletrem ispraeniz c paverknosti sushi [Of the average long-term evaporation from land surface]. Meteorol Gidrol, 10, 20-25.

Chiew, F.H.S., P.H. Whetton, T.A. McMahon and A.B. Pittock. 1995. Simulation of the impacts of climate change on runoff and soil moisture in Australian catchments. J. Hydrol., 167(1-4), $121-147$

Dyurgerov, M. 2002. Glacier mass balance and regime: data of measurements and analysis. Boulder, CO, University of Colorado. Institute of Arctic and Alpine Research. (INSTAAR Occasional Paper 55.)

Fujita, K. and 6 others. 2006. Thirty-year history of glacial melting in the Nepal Himalayas. J. Geophys. Res., 111(D3), D03109. (10.1029/2005JD005894.)

Guan, Z. and 9 others. 1984. Rivers and lakes of Xizang: the series of the scientific expedition to the Qinghai-Xizang plateau. Beijing, Science Press. [In Chinese.]

Liu, T. 1995. Changes of Yamzho Lake water stage in Xizang. Sci. Geogr. Sin., 15(1), 55-62. [In Chinese with English summary.]

Mayewski, P.A. and P.A. Jeschke. 1979. Himalayan and transHimalayan glacier fluctuations since A.D. 1812. Arct. Alp. Res., 11(3), 267-287.

Shi, Y. and J. Ren. 1990. Glacier recession and lake shrinkage indicating a climatic warming and drying trend in central Asia. Ann. Glaciol., 14, 261-265.

Yao, T.D., Y.Q. Wang, S.Y. Liu, J.C. Pu, Y.P. Shen and A.X. Lu. 2004. Recent glacial retreat in High Asia in China and its impact on water resource in Northwest China. Sci. China D, 47(12), 1065-1075.

Ye, Q., T. Yao, S. Kang, F. Chen and J. Wang. 2006a. Glacier variations in the Naimona'nyi region, western Himalaya, in the last three decades. Ann. Glaciol., 43, 385-389.

Ye, Q., S. Kang, F. Chen and J. Wang. 2006b. Monitoring glacier variations on Geladandong mountain, central Tibetan Plateau, from 1969 to 2002 using remote-sensing and GIS technologies. J. Glaciol., 52(179), 537-545. 